\title{
EFFICIENCY OF OIL PALM SMALLHOLDERS IN INDONESIA: A META-FRONTIER APPROACH
}

\author{
Firna Varina ${ }^{* 1}$, Sri Hartoyo ${ }^{* *}$, Nunung Kusnadi***), and Amzul Rifin ${ }^{* * *}$ \\ *) Department of Agribusiness, Graha Karya School of Agriculture \\ Jl. Gajah Mada Muara Bulian, Jambi 36613, Indonesia \\ ${ }^{* *}$ Department of Economics, Faculty of Economics and Management, IPB University \\ Jl. Agatis, Campus of IPB Darmaga Bogor 16680, Indonesia \\ ${ }^{* * *}$ Department of Agribusiness, Faculty of Economics and Management, IPB University \\ Jl. Agatis, Campus of IPB Darmaga Bogor 16680, Indonesia
}

\begin{abstract}
This research aims to evaluate the performance production and technical efficiency of oil palm production in Indonesia based on the management pattern (independent farmers and supported farmers). The secondary data were used from the Estate Cultivation Household Survey (ST2013 SKB) conducted by BPS-Statistics Indonesia. The empirical analysis involved using a meta-frontier approach, allowing one to decompose efficiency into grouplevel technical efficiency and technology gaps. The results indicate that the output of each management pattern behind their potential with the mean technical efficiency of 0,6789 and 0,7127 for independent farmers and supported farmers, respectively. The technology gap ratio statistics showed that the farmers had adopted the best available smallholder production technology in their farming. However, independent farmers were slightly more optimal than supported farmers. The efficiency measure generated from the meta-frontier revealed that supported farmers were more efficient, where the primary source of inefficiency came from managerial inefficiency. Thus, the policies to increase the production of oil palm smallholders must focus on the improvement of technical skills and managerial capabilities of farmers on the efficient use of resources and advanced technology by considering each characteristic of each management pattern.
\end{abstract}

Keywords: technical efficiency, independent farmers, supported farmers, oil palm, metafrontier

Abstrak: Studi ini bertujuan mengevaluasi kinerja produksi dan efisiensi teknis produksi kelapa sawit rakyat di Indonesia menurut pola pengelolaan (pekebun mandiri dan pekebun mitra) menggunakan data dari Survei Usaha Rumah Tangga Perkebunan 2014 yang telah dilakukan oleh Badan Pusat Statistik. Analisis empiris dilakukan dengan menggunakan pendekatan stokastikmeta-frontier, yang memungkinkan kita untukmendekomposisi efisiensi menjadi efisiensi teknis dan kesenjangan teknologi. Hasil studi menunjukkan produksi masing-masing pola pengelolaan berada di bawah potensi produksinya dengan rata-rata efisiensi teknis 0,6789 dan 0,7127 untuk pekebun mandiri dan pekebun mitra. Statistik rasio kesenjangan teknologi menunjukkan petani telah mengadopsi teknologi produksi terbaik yang tersedia pada perkebunan kelapa sawit rakyat, namun pekebun mandiri sedikit lebih optimal dibandingkan pekebun mitra. Ukuran efisiensi yang dihasilkan dari meta-frontier menunjukkan bahwa pekebun mitra lebih efisien dibandingkan pekebun mandiri dimana sumber utama inefisiensi berasal dari inefisiensi managerial. Untuk itu, kebijakan dalam meningkatkan produksi kelapa sawit rakyat harus difokuskan pada peningkatan ketrampilan teknis dan kapabilitas manajerial pekebun dan penggunaan teknologi baru yang lebih maju dengan mempertimbangkan karakteristik dari masing-masing pola pengelolaan.

Kata kunci: efisiensi teknis, pekebun mandiri, pekebun mitra, kelapa sawit, meta-frontier

${ }^{1}$ Corresponding author:

Email: firna33@ymail.com 


\section{INTRODUCTION}

Indonesia is the largest oil palm-producing country in the world. Its production (in the form of crude palm oil) was recorded to represent more than $56 \%$ of total world production, reaching 71.45 million tons in 2018 (FAO, 2020). Oil palm is a leading commodity from the estate sector in Indonesia, becoming a source of foreign exchange earnings and economic drivers in rural areas.

The development of oil palm plantations has impacted natural habitats, biodiversity, and global climate (Rist et al. 2010). It has long been associated with deforestation and environmental destruction (Euler et al. 2016a; Gatto et al. 2017). Regardless of the pros and cons of adverse effects, oil palm remains an attractive opportunity for improving farmers' welfare in most regions in Indonesia.

Apart from smallholder plantations, Indonesia's oil palm is also cultivated by large farms by both state and private plantations. Of the three types of exploitation in 2018, smallholders controlled $40.61 \%$ of Indonesia's oil palm area (5.82 million hectares) with 15.30 million tons (CPO) and productivity of 3.37 tons/hectare. It also absorbed nearly 2.6 million workers (Ditjenbun, 2019). Of the three types of exploitation, smallholder plantations operated by farmer households have the lowest productivity, showing that the farmers operate still far below their best potential.

The low productivity of oil palm farmers allegedly because the allocation of input usage is not optimal and different cultivation techniques among farmers. The managerial capability of farmers in managing and allocating production input will influence the technical efficiency. Farmers who, in their cultivation techniques, can manage the use of production factors to achieve maximum production yields can be said to be efficient. It is necessary to investigate the factors that influenced production and technical efficiency in smallholder plantations.

There are two primary farmers based on their farming management patterns: partner/supported farmers and independent farmers. Supported farmers initiated the cultivation of oil palm through contracts with large companies, both private and government. Meanwhile, independent farmers operate without support and adopt farming technology independently (Euler et al. 2016b). They are free to manage their plantations. The partnership pattern is that large plantation companies and operating their farms also help smallholders in the vicinity. The companies provide support to farmers that include seed and fertilizers and also technical assistance.

Technological differences in farm management lead to differences in production. Farmers in different circumstances (such as logistics and systems) face other production opportunities and make choices from different technological sets with varying sets of feasible input and output (Kramol et al. 2015). The technical efficiency of farmers operating on different production technologies cannot be compared to the same production frontier (O'Donnell et al. 2008). A meta-frontier approach is used to compare the patterns of smallholder oil palm plantation patterns as it can show the level of disparity in production technology between the two farming practices.

Research using a meta-frontier approach on oil palm smallholders in Indonesia has never been carried out. Several previous studies assessed efficiency as still partial and had not seen variations in conditions between groups of smallholders and did not use maximum potential as a reference for comparison. The comparison was not valid.

This study aims to investigate the performance production and technical efficiency of oil palm smallholders in Indonesia by considering the comparability of frontier sizes among oil palm farmer groups according to management patterns.

\section{METHODS}

The research-based data included secondary data in cross-section data from the 2014 Estate Cultivation Household Survey (ST2013 SKB) by BPS-Statistics Indonesia. The sample comprised 21,040 selected oil palm smallholder farmers in 2013. 18,003 farmers are independent patterns, while the remaining 3,037 are supported/business partnership patterns.

\section{Meta-Frontier Analysis}

The stochastic frontier model has been widely used to estimate technical efficiency in applied economic research. This approach uses a single production 
function based on the assumption that the underlying technology is the same for all the sample observations (Alem et al. 2018). On the other hand, metafrontier analysis accounts for heterogeneity in farm technologies across groups (e.g. Battese et al. 2004; O'Donnell et al. 2008). The efficiencies relative to the meta-frontier production function consist of three components: 1) efficiency measures (TE) derived from the group frontiers, corresponding to the distance between the observed input-output of ith farmer and the group frontier, 2) the technology gap ratios (TGR) corresponding to the distance between the group frontier and the meta-frontier, and 3) the meta-frontier technical efficiency (MTE) which measures the distance from the observed input-output of ith farmer to the meta-frontier. The importance of measuring MTE is that it allows us to make eficiency comparisons of farming households across groups (Khanal et al. 2018).

In this study, the estimation of technical efficiency was carried out using the methodology proposed by Huang et al. (2014). A two-stage stochastic frontier approach was used to estimate the group frontier and meta-frontier and decompose the efficiency figures into technical efficiency and technology gaps; as follows:

$$
\mathrm{Y}_{\mathrm{ji}}=\mathrm{f}_{\mathrm{j}}\left(\mathrm{X}_{\mathrm{ji}}\right) \mathrm{e}^{\left(\mathrm{V}_{\mathrm{ji}} \mathrm{U}_{\mathrm{ji}}\right)} \quad \mathrm{j}=1,2, \ldots \mathrm{J} \quad \mathrm{i}=1,2, \ldots \mathrm{Nj}
$$

Where is $Y_{\mathrm{ji}}$ denotes the output and $\mathrm{X}_{\mathrm{ji}}$ the input vector of the ith production unit in the group $j$ th; $\mathrm{V}_{\mathrm{ji}}$ is the noise that cannot be fully controlled by the farmer and it is assumed to be a normally-distributed random variable with zero means and variance $\sigma^{2}{ }_{\mathrm{v}} ; \mathrm{V}_{\mathrm{ji}} \sim \mathrm{N}\left(0, \sigma^{\mathrm{j} 2}{ }_{\mathrm{v}}\right) ; \mathrm{U}_{\mathrm{ji}}$ represents technical inefficiency $\mathrm{U}_{\mathrm{ji}} \sim \mathrm{N}^{+}\left(\mu^{\mathrm{j}}\left(\mathrm{Z}_{\mathrm{ji}}\right), \sigma^{\mathrm{j} 2}{ }_{\mathrm{v}}\right)$. It is assumed that $\mathrm{V}_{\mathrm{ji}}$ is independent of $\mathrm{U}_{\mathrm{ji}}$, which follows a truncated-normal distribution, where $Z_{\mathrm{ji}}$ is a set of environmental variables. Technical efficiency (TE) in production is defined as

$\mathrm{TE}_{\mathrm{ji}}=\frac{\mathrm{Y}_{\mathrm{ji}}}{f^{j}\left(x_{j i}\right) e^{V_{j i}}}=e^{-U_{j i}}$

The meta-frontier production function is defined as $\mathrm{f}^{\mathrm{M}}\left(\mathrm{X}_{\mathrm{ji}}\right)$, envelops all the group-specific frontiers $\mathrm{ff}^{\mathrm{f}}\left(\mathrm{X}_{\mathrm{ji}}\right)$. The following relationship explains it

$$
f^{j}\left(X_{j i}\right)=f^{M}\left(X_{j i}\right) e^{-U_{j i}^{M}} \quad \forall \mathrm{j}, \mathrm{i}
$$

Where $\mathrm{U}^{\mathrm{M}}{ }_{\mathrm{ji}} \geq 0$ so that $\mathrm{f}^{\mathrm{M}}(.) \geq \mathrm{f}^{\mathrm{f}}($.$) and the relationship$ of the production frontier $j$ th to the meta-frontier is defined as the technology gap ratio:

$$
T G R_{i}^{j}=\frac{f^{j}\left(x_{j i}\right)}{f^{M}\left(x_{j i}\right)}=e^{-U_{j i}^{M}} \leq 1
$$

According to Huang et al. (2014), the technology gap depends on the accessibility and extent of adoption of the available meta-frontier production technology. In this second stage, we estimate the stochastic meta-frontier without the inclusion of environmental variables. They explained that at a given level of input $X_{\mathrm{ji}}$, output $\mathrm{Y}_{\mathrm{ji}}$ relative to meta-frontier $\mathrm{f}^{\mathrm{M}}\left(\mathrm{X}_{\mathrm{j}}\right)$ that can be decomposed into three components: technology gap ratio (TGR), technical efficiency (TE), and random noise.

$$
\frac{Y_{j i}}{f^{M}\left(x_{j i}\right)}=T G R_{i}^{j} x T E_{i}^{j} x e^{V_{j i}}
$$

Taking the random noise component into account, the equation above can be expressed alternatively as:

$$
M T E_{j i} \equiv \frac{Y_{j i}}{f^{M}\left(x_{j i}\right) e^{V_{j i}}}=T G R_{i}^{j} x T E_{i}^{j}
$$

Where $\mathrm{MTE}_{\mathrm{ji}}$ is defined as the firm's technical efficiency concerning the meta-frontier production technology.

\section{Empirical Model}

The management of oil palm farming was faced with technical and socio-economic constraints, which caused the farmers to be inefficient in using inputs for maximum output. The oil palm production is influenced by the availability of inputs such as productive trees, labor, fertilizers, and pesticides. The socio-economic factors included age, education, extension service, farmer group membership, ownership of farmland, and funding sources. These factors were analyzed using a stochastic frontier production function to know the technical efficiencies of farmers by management pattern. The frontier group of management patterns is the basis for determining the meta-frontier function. The theoretical framework can be seen in Figure 1.

The empirical model of the frontier stochastic production function in this study is used a translog functional form

$$
\begin{aligned}
\ln Y_{i}= & \beta_{0}+\sum_{j=1}^{5} \beta_{j} \ln X_{j i}+\frac{1}{2} \sum_{j=1}^{5} \sum_{k=1}^{5} \beta_{j k} \ln X_{j i} \ln X_{k i} \\
& +\left(V_{i}-U_{i}\right)
\end{aligned}
$$


Where $\mathrm{Y}_{\mathrm{i}}$ is the fresh fruit bunch (FFB) production by the ith farmer (kilograms), $X_{1}$ is the age of productive plants (year), $\mathrm{X}_{2}$ is the number of the productive trees (trees), $X_{3}$ is the total quantity of labor used (mandays), $\mathrm{X}_{4}$ is the number of chemical fertilizers used (kilograms), $\mathrm{X}_{5}$ is the amount the pesticides used (liters), $\mathrm{V}_{\mathrm{i}}$ and $\mathrm{U}_{\mathrm{i}}$ have their usual meaning, $\beta_{\mathrm{j}}$ is parameter estimates.

The method of measuring technical inefficiency refers to the technical inefficiency effect model from Battese and Coelli (1995) which it had also been used by MeloBecerra and Orozco-Gallo (2017), Khanal et al. (2017), Asravor et al. (2019), Danso-Abbeam and Baiyegunhi (2019). The environmental variable in the measurement of technical inefficiency, $\mathrm{Zi}$, consists of socio-economic factors. The equation is specified as:

$$
U_{i}=\delta_{0}+\sum_{j=1}^{6} \delta_{j} Z_{j i}
$$

where $\mathrm{Z} 1$ denotes the farmer age (years), Z2 denotes the length of education (years), Z3 has a value of 1 if the farmer receives extension services, and 0 if otherwise. $\mathrm{Z} 4$ has a value of 1 if the farmer is a member of the farmer group and 0 if otherwise. Z5 is the dummy with a value of 1 if the land is owned by the farmer and 0 if otherwise. Z6 has a value of 1 if the farmer receives a credit to financing their farms and 0 if otherwise, and $\delta \mathrm{j}$ is the vector to be estimated coefficients.

\section{Test of Hypotheses}

Hypotheses' tests are examined to determine the adequacy of the adopted model. The hypotheses are carried out to test the functional form of the production function, non-stochastic effects on the production function, technical inefficiency, and use of the metafrontier. The null hypotheses are (1) $\mathrm{H} 0: \beta \mathrm{ij}=0 \mathrm{i} \neq \mathrm{j}$, the second-order parameter of the translog form is zero ; (2) H0: $\gamma=0$, the effect of production inefficiency is non-stochastic (3) $\mathrm{H} 0: \gamma=\delta 0=\delta 1=\delta 2=\ldots \ldots \delta 6=0$. There is no inefficiency effect in the model at all levels; (4) H0: find $(X, \beta$ ind $)=f \sup (X, \beta$ sup $)$, the two patterns of public plantation production technology are similar, so there is no need for the specification of the metafrontier model.

The generalized likelihood-ratio statistic (LR), $\lambda=$ $-2\left\{\ln \left[\mathrm{L}\left(\mathrm{H} \_0\right)\right]-\ln \left[\mathrm{L}\left(\mathrm{H} \_1\right)\right]\right\}$ is used to validate these hypotheses, where $\mathrm{L}(\mathrm{H} 0)$ and $\mathrm{L}(\mathrm{H} 1)$ denote the loglikelihood function values for the null $(\mathrm{H} 0)$ and alternative (H1) hypotheses, respectively. Critical values were taken from Table of Kodde and Palm.

\section{RESULTS}

\section{Fitness of adopted model}

The results of the hypotheses tested are shown in Table 1. The first hypothesis showed that the translog's functional form was better than Cobb-Douglas in representing the data. The second hypothesis stating that the effect of inefficiency is non-stochastic was rejected. So in this model, the study used the translog stochastic frontier production function. Finding from the third hypothesis confirmed that there were inefficiency effects in both management pattern models. In the fourth hypothesis test, the null hypothesis stating that technologies used under both of the management patterns are the same was rejected. The meta-frontier approach was suitable for comparing the efficiency between the two patterns of management of smallholder oil palm plantations. This evidence supports the fact that the farmers are operating under heterogeneous technologies.

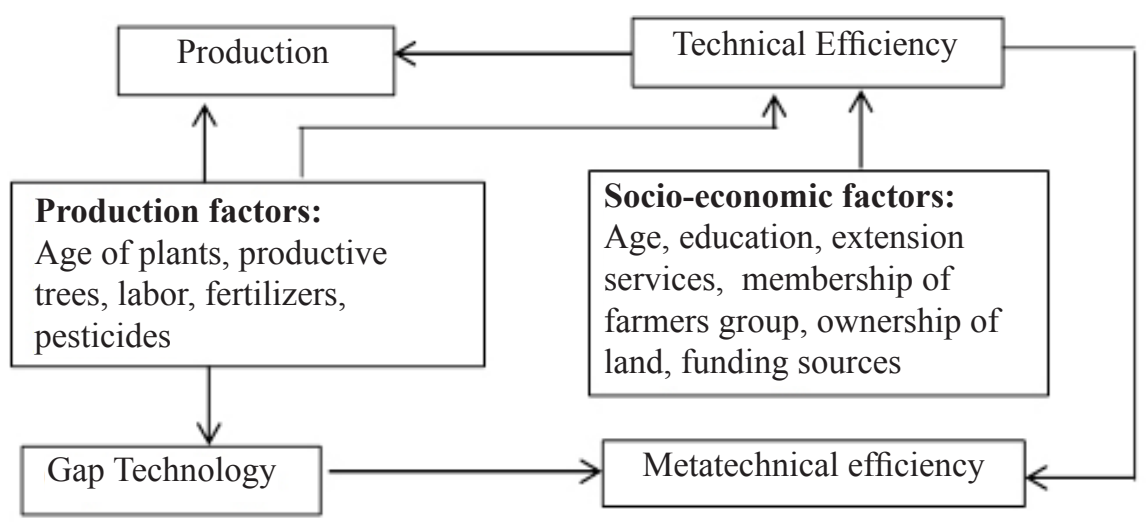

Figure 1. Research framework 
Table 1. Results of the hypotheses tested

\begin{tabular}{lccc}
\hline Null Hypotheses & Statistics LR $(\lambda)$ & Critical values $\chi^{2} 0,01$ & Decision \\
\hline Ho : $\beta \mathrm{ij}=0$ & & & \\
Independent farmers & 1,542 & 29.93 & Reject Ho \\
Supported farmers & 443 & 29.93 & Reject Ho \\
Ho : $\gamma=0$ & & & \\
Independent farmers & 2,313 & 5.41 & Reject Ho \\
Supported farmers & 530 & 5.41 & Reject Ho \\
Ho : $\gamma=\delta 0=\delta 1 \ldots \delta 6=0$ & & & \\
Independent farmers & 64 & 17.76 & Reject Ho \\
Supported farmers & 39 & 17.76 & Reject Ho \\
Ho : find(X; $\beta$ ind)=fsup(X; $\beta$ sup) & 190 & 38.30 & Reject Ho \\
\hline
\end{tabular}

\section{Estimation of the Stochastic Frontier Production Function}

Table 2 shows the MLE estimation parameters resulting from the stochastic frontier model and metafrontier of oil palm smallholder farmers in Indonesia. The estimation results described the best performance of the farmers at the available technology level. The coefficients of production function variables were positive. All variables considered in the production function, i.e., age of plants, productive trees, labor, chemical fertilizers, and pesticides had a significant effect in explaining the variation in oil palm production of supported farmers, meanwhile four variables (age of plants, productive trees, labor, chemical fertilizers) in independent farmers. All inputs used in the production function are inelastic, implying that a 1 percent increase in every input will lead to a less than 1 percent increase in FFB output. On average, as the independent farmer increase productive tress, labor, amount of chemical fertilizer application, and amount of pesticides application by 1 percent each, he can increase the level of FFB output by $0.690,0.222,0.046$, and 0.001 percent, respectively; on the other hand, the supported farmer can increase the level of FFB output by 0.655 ; $0.180 ; 0.091$; and 0.012 percent respectively.

The variable number of productive trees had the highest elasticity in both management patterns, which implies that a percentage increase in the land size has a more considerable influence on oil palm production than other inputs. This finding was consistent with Juyjaeng et al.'s (2018) study on farmers who were not members of the Large Agricultural Plot Scheme (LAPS) in Thailand. The variable of productive trees was more responsive in independent farmers group than supported farmers and the age of plant input. The average plant age of independent farmers was 8.8 years, which had just entered the beginning of the peak production period. In comparison, supported farmers' plants would enter the end of the peak production period of 14.6 years.

Besides, labor input in independent farmers group was more responsive than in supported farmers. It is presumably because the age of younger plants in independent farmers group is relatively more laborintensive than supported farmers group. The positive labor coefficient is consistent with the studies of Hasnah et al. (2004), Onumah et al. (2003), Danso-Abbeam and Baiyegunhi (2019).

The positive effect of fertilizer use on oil palm production is consistent with the results of the study of Hasnah et al. (2004), Alwarritzi et al. (2015), and Ramli (2013). Furthermore, this study showed that the fertilizer input on oil palm production in the supported farmers' group was more responsive than independent farmers. It is proven by the dose of fertilizer application by independent farmers $(3.64 \mathrm{~kg} /$ tree $)$ and supported farmers $(5.32 \mathrm{~kg} /$ tree). Many independent smallholders do not apply the appropriate amount and type of fertilizers because of less financial support and access to production factors (Chalil and Barus, 2019).

The results also showed that pesticide use by smallholders increases oil palm production in a very small part. Independent farmers group use relatively more pesticides than supported farmers. It is because young plants are susceptible to pests and diseases, so they need more pesticides to control. Its application must be handled carefully because it will reduce production if given the wrong amount and time. 
Table 2. Parameter estimates of stochastic frontier and meta-frontier

\begin{tabular}{|c|c|c|c|c|c|c|c|c|c|}
\hline \multirow[t]{2}{*}{ Variable } & \multicolumn{3}{|c|}{ Independent } & \multicolumn{3}{|c|}{ Supported } & \multicolumn{3}{|c|}{ Metafrontier } \\
\hline & Coeff & & Std Err & Coeff & & Std Err & Coeff & & Std Err \\
\hline Constant & 3.0883 & $* * *$ & 0.1407 & 2.8560 & $* * *$ & 0.4854 & 3.1428 & $* * *$ & 0.0075 \\
\hline In age of trees (lupn) & 1.5414 & $* * *$ & 0.0675 & 1.4925 & $* * *$ & 0.2161 & 1.4687 & $* * *$ & 0.0044 \\
\hline ln productive trees (lpn) & 0.9205 & $* * *$ & 0.0523 & 1.0473 & $* * *$ & 0.1887 & 0.9121 & $* * *$ & 0.0031 \\
\hline ln labor (lttk) & 0.0877 & $* *$ & 0.0404 & 0.0712 & & 0.1526 & 0.1039 & $* * *$ & 0.0027 \\
\hline In chemical fertilizer (lppk) & 0.0344 & $* * *$ & 0.0044 & 0.0228 & & 0.0166 & 0.0352 & $* * *$ & 0.0002 \\
\hline ln pesticide (lpes) & -0.0068 & & 0.0063 & 0.0651 & $* * *$ & 0.0160 & 0.0012 & $* *$ & 0.0005 \\
\hline $0,5 \times$ lupn $^{2}$ & -0.5303 & $* * *$ & 0.0266 & -0.4118 & $* * *$ & 0.0660 & -0.4915 & $* * *$ & 0.0020 \\
\hline $0,5 \times 11 p n^{2}$ & -0.0236 & & 0.0152 & -0.0006 & & 0.0485 & -0.0210 & $* * *$ & 0.0009 \\
\hline $0,5 \times 1 t k^{2}$ & 0.0562 & $* * *$ & 0.0057 & 0.0508 & $* *$ & 0.0239 & 0.0555 & $* * *$ & 0.0006 \\
\hline $0,5 \times \operatorname{lppk}^{2}$ & 0.0069 & $* * *$ & 0.0005 & 0.0097 & $* * *$ & 0.0013 & 0.0074 & $* * *$ & 0.0000 \\
\hline $0,5 \times$ lpes $^{2}$ & 0.0006 & & 0.0007 & 0.0056 & $* * *$ & 0.0016 & 0.0012 & $* * *$ & 0.0001 \\
\hline lupn x llpn & -0.0199 & & 0.0142 & -0.1032 & $* * *$ & 0.0330 & -0.0194 & $* * *$ & 0.0013 \\
\hline lupn x lttk & -0.0165 & & 0.0124 & 0.0234 & & 0.0280 & -0.0193 & $* * *$ & 0.0012 \\
\hline lupn x lppk & 0.0017 & $*$ & 0.0009 & 0.0051 & $*$ & 0.0031 & 0.0023 & $* * *$ & 0.0001 \\
\hline lupn $x$ lpes & 0.0036 & $* * *$ & 0.0009 & -0.0057 & $* * *$ & 0.0019 & 0.0022 & $* * *$ & 0.0001 \\
\hline llpn x lttk & -0.0154 & $* *$ & 0.0075 & -0.0327 & & 0.0306 & -0.0173 & $* * *$ & 0.0007 \\
\hline llpn x lppk & 0.0029 & $* * *$ & 0.0009 & 0.0031 & & 0.0035 & 0.0028 & $* * *$ & 0.0001 \\
\hline llpn x lpes & 0.0023 & $* *$ & 0.0010 & -0.0048 & $*$ & 0.0026 & 0.0016 & $* * *$ & 0.0001 \\
\hline lttk x lppk & -0.0048 & $* * *$ & 0.0008 & -0.0022 & & 0.0027 & -0.0047 & $* * *$ & 0.0001 \\
\hline lttk x lpes & -0.0017 & $* *$ & 0.0008 & 0.0023 & & 0.0020 & -0.0013 & $* * *$ & 0.0000 \\
\hline lppk x lpes & -0.0001 & & 0.0001 & -0.0003 & $*$ & 0.0002 & -0.0001 & $* * *$ & 0.0000 \\
\hline \multicolumn{10}{|l|}{ Environmental Variables } \\
\hline Constant & -8.1416 & $* * *$ & 3.0955 & -227.5847 & $* * *$ & 63.0377 & & & \\
\hline Age of farmers & -0.0446 & $* * *$ & 0.0165 & 0.3110 & & 0.7585 & & & \\
\hline Education & -0.1183 & $* * *$ & 0.0458 & 1.0036 & & 2.3582 & & & \\
\hline Extension services & -1.4527 & $*$ & 0.8057 & -36.1923 & & 23.7914 & & & \\
\hline Membership of farmer group & -1.0687 & $* *$ & 0.4532 & -55.9291 & $* * *$ & 17.2587 & & & \\
\hline Ownership of farmland & -2.0073 & $* *$ & 0.8661 & -167.0947 & $* * *$ & 40.4174 & & & \\
\hline Funding sources & -1.4746 & $* *$ & 0.6374 & 78.3661 & $* * *$ & 17.2706 & & & \\
\hline \multicolumn{10}{|c|}{ Variance and other model statistics } \\
\hline sigma_u & 2.5930 & $* * *$ & 0.3793 & 12.7178 & $* * *$ & 0.3061 & 0.4866 & $* * *$ & 0.0171 \\
\hline sigma_v & 0.2895 & $* * *$ & 0.0051 & 0.2531 & $* * *$ & 0.0095 & 0.0262 & $* * *$ & 0.0005 \\
\hline lambda & 8.9572 & $* * *$ & 0.3777 & 50.2411 & $* * *$ & 0.3109 & 18.6079 & $* * *$ & 0.0173 \\
\hline Log-likelihood & -13040 & & & -1805 & & & & & \\
\hline \multicolumn{10}{|l|}{ Output Elasticities } \\
\hline Age of plants & 0.2766 & & & 0.0399 & & & & & \\
\hline Productive trees & 0.6900 & & & 0.6555 & & & & & \\
\hline Labor & 0.2220 & & & 0.1796 & & & & & \\
\hline Chemical Fertilizer & 0.0462 & & & 0.0908 & & & & & \\
\hline Pesticide & 0.0011 & & & 0.0123 & & & & & \\
\hline Return To Scale & 1.2359 & & & 0.9782 & & & & & \\
\hline
\end{tabular}

Notes: * significant at $10 \% ; * *$ significant at $5 \%, * * *$ significant at $1 \%$ 
The sum of all parts of output elasticities equaled 1.2359 , indicating an increasing return to scale (IRS) in independent farmers' oil palm production. This indicates an opportunity for independent farmers to expand their scales to increase production in the long run. On the contrary, supported farmers exhibit a decreasing return to scale (DRS) of 0.9782. It implied that a proportional increase in all input used results in a less than proportional increase in FFB output.

\section{Technical Efficiency and Technology Gap Ratio}

The technical inefficiency model was calculated simultaneously with the production function for each management pattern. Table 3 showed the distribution of Technical efficiency (TE), technology gap ratio (TGR), and Meta-technical efficiency (MTE). There was an excellent dispersion of TE scores among households within management patterns. The average technical efficiency of supported farmers is 0.7127 , and that of independent farmers was 0.6789 based on the benchmark for each frontier. It meant that to be fully efficient towards the frontier, independent and supported farmers need to increase production by $32 \%$ and $29 \%$, respectively, without using additional resources. It does not mean that independent farmers have lower performance than supported farmers because these TE values across management patterns are not comparable.

The mean of technology gap ratio (TGR) scores showed that independent farmers seem to be slightly more efficient in adopting the best available smallholder production technology than supported farmers. The TGR score for independent farmers was 0.9878 and 0.9823 for supported farmers. It was presumably because not all supported farmers utilized available technology optimally. Partnership model with state-owned enterprises (BUMN), regional-owned enterprises, and private enterprises presumed influence a variety of supported farmers' TGR.

Overall, supported farmers' farming was more technically efficient in production than independent farmers concerning oil palm smallholders in Indonesia as measured by the MTE. The scores of TEs, TGRs, and MTEs suggested that the primary source of inefficiency comes from managerial inefficiency rather than the technology undertaken.

\section{Determinants of Technical Inefficiency Level}

Estimates of determinants of technical inefficiency are presented in the middle section of Table 2. A negative effect of a particular variable on technical inefficiency indicates a positive impact on TE. Socio-economic variables, i.e., farmer age, education, extension service, farmer group membership, land ownership, and funds sources, would significantly improve independent farmers' TE. On the other hand, only the membership of farmer groups and land ownership variables had positive effects on supported farmers' technical efficiency, while credit had a negative impact. The variables of farmer age, education, and extension did not affect supported farmers' technical efficiency.

The farmers' age factor had a negative and significant coefficient sign for independent farmers, but a positive and insignificant sign for supported farmers. It meant that older independent farmers tend to be more efficient than younger farmers. This shows that the farming experience factor has a positive effect on TE.

Table 3. Technical efficiency for oil palm smallholders

\begin{tabular}{lllll}
\hline Variable & Mean & Std. Dev. & Min & Max \\
\hline Independent Farmers & & & & \\
TE & 0.6789 & 0.1885 & 0.0489 & 0.9518 \\
TGR & 0.9878 & 0.0028 & 0.9163 & 0.9934 \\
MTE & 0.6706 & 0.1863 & 0.0483 & 0.9421 \\
Supported Farmers & & & & \\
TE & 0.7127 & 0.1819 & 0.0649 & 0.9546 \\
TGR & 0.9823 & 0.0276 & 0.6952 & 0.9981 \\
MTE & 0.7004 & 0.1800 & 0.0643 & 0.9528 \\
\hline
\end{tabular}


In terms of composition, more than $50 \%$ of independent farmers were over 45 years old. The farmers had experience in farming, so that the decisions taken would affect efficiency. The study results by Hasnah et al. (2004) also showed a negative sign of the farmer age coefficient, which was not significant, however.

The farmer's level of education had a negative and statistically significant coefficient for independent farmers. It meant that the education level of oil palm farmers might improve technical efficiency. These results were consistent with the study by Ngango and Kim (2019), Alwarritzi et al. (2015), and Kittilertpaisan et al. (2016). With higher education, farmers have a broader mindset and insight so that they will be able to improve efficiency in farming. On the other hand, for supported farmers, the education coefficient was positive but not significant. The effect of education on the technical efficiency of supported farmers was not supported.

Another factor that influenced TE is the extension service. The variable coefficient on both management patterns was negative, although not significant for supported farmers. The negative coefficient meant that extension service activities would affect better efficiency. With the extension, farmers will get new technical innovations in cultivation and communication links between farmers and extension workers to improve efficiency. Onumah et al. (2013) and Ngango and Kim (2019) also proved a significant positive relationship between extension and efficiency. Along with extension services, the farmer group membership coefficient was negative and significant. It meant that being a member of a farmer group could improve technical efficiency.

The land is the main asset of farmers in managing their plantations. The findings revealed that owned land status had a significant effect on efficiency, both for independent and supported farmers. Clear land ownership status without land conflicts makes farmers more eager and efficient to manage their plantations because of their sense of belonging. The positive effect of land ownership on technical efficiency was consistent with the study of Asravor et al. (2019) in the forest-savannah transition zone of Ghana and Koirola et al. (2016).
Sources of financing had a significant effect on efficiency, both for independent and supported farmers. However, it comes with the opposite sign. For independent farmers, the existence of credit in their farm financing had a positive effect on on-farm efficiency. On the other hand, the supported farmers had a negative impact. Independent farmers are farmers with limited capital, so they need capital assistance from financial institutions to finance their farming. On the other hand, the supported farmers have received help from companies or cooperatives, so it was presumed that the existence of loans thought to make farmers not allocate funds for their farming, thus making it inefficient. The positive effect of credit on technical efficiency has been stated in the study of Onumah et al. (2013) and Ngango and Kim (2019).

\section{Managerial Implication}

Participating in partnership has a positive effect in improving crop production and technical efficiency of oil palm smallholders farming. Stakeholders and the Indonesian Government need to increase farmers' capacities and capabilities to improve productivity and technical efficiencies of oil palm smallholders. It is necessary to improve the performance of existing business partnerships and the need to encourage independent farmers to enter into a business partnership.

\section{CONCLUSIONS AND RECOMMENDATIONS}

\section{Conclusions}

Oil palm production is relatively heterogeneous within the management pattern of smallholders. As expected, the observed output was lower than their potential output. All the input variables in this study have a positive effect on FFB output. The independent farmers exhibit the IRS scale, while supported farmers exhibit the DRS. The plants' age mainly determined the production level, the number of productive trees, labor, and chemical fertilizers. The study also identified the effects of some socioeconomic variables as sources of technical ineffciencies. The estimated value of TGR showed that both independent farmers and supported farmers had adapted the best production technology in their farming. Concerning oil palm smallholder 
production in Indonesia as measured by the MTE, supported farmers' farming was more efficient than independent farmers. Both management patterns were operating beneath their frontier so that there was room to improve their technical skills and managerial capabilities.

\section{Recommendations}

The results suggested that intervention aimed at efficiency improvement of independent farmers' production should be promoted through education in the rural areas, socialization on agricultural practices for young farmers, enhancement of farmers' access to relevant training programs by empowering extension workers, targeting all farmers in all locations. In this regard, extension service institutions should be strengthened by improving the human resource capacity of extension workers and the information dissemination system. The government should support farmers to get access to credit and ease land ownership. For supported farmers, designing a farmer empowerment program in a farmer group forum and making it easier for farmers to own the land will be very helpful.

\section{ACKNOWLEDGMENT}

We gratefully acknowledge the financial support provided by Indonesian Endowment Fund for Education (LPDP), Ministry of Finance of The Republic of Indonesia.

\section{REFERENCES}

Abdullah R. 2013. Technical efficiency of independent oil palm smallholders ( ISH ) in Peninsular Malaysia with respect to fertiliser and land size. Oil Palm Industry Economic Journal 13(2): 2737.

Alem H, Lien G, Hardaker B, Guttormsen A. 2018. Regional differences in technical efficiency and technological gap of Norwegian dairy farms: a stochastic meta-frontier model. Applied Economics. https:// doi.org/10.1080/00036846.2 018.1502867.

Alwarritzi W, Nanseki T, Chomei Y. 2015. Analysis of the factors influencing the technical efficiency among oil palm smallholder farmers in Indonesia. Procedia Environmental Science 28(SustaiN
2014): $\quad 630-638 . \quad$ https://doi.org/10.1016/j. proenv.2015.07.074.

Asravor J, Wiredu AN, Siddig K, Onumah EE. 2019. Evaluating the environmental-technology gaps of rice farms in distinct agro-ecological zones of Ghana. Sustainability (Switzerland) 11(7): 1-16. https://doi.org/10.3390/su11072072.

Baswir R et al. 2010. Pekebun Mandiri dalam Industri Perkebunan Sawit di Indonesia. Yogyakarta: Sawit Watch, Serikat Petani Kelapa Sawit, Pusat Studi Ekonomi Kerakyatan UGM.

Battese GE, Coelli TJ. 1995. A model for technical inefficiency effects in a stochastic frontier production function for panel data. Empirical Economics 20(2): 325-332. https://doi. org/10.1007/BF01205442.

Battese GE, Rao DSP, O’Donnell CJ. 2004. A metafrontier production function for estimation of technicalefficienciesandtechnologygapsforfirms operating underdifferent technologies. Journalof Productivity Analysis 21(1): 91-103. https://doi. org/10.1023/B:PROD.0000012454.06094.29.

Chalil D, Barus R. 2019. Risk analysis for sustainability of oil palm smallholdings. Jurnal Manajemen dan Agribisnis 16(1): 23-29. https://doi. org/10.17358/jma.16.1.23.

Danso-Abbeam G, Baiyegunhi LJS. 2019. Technical efficiency and technology gap in Ghana's cocoa industry: accounting for farm heterogeneity. Applied Economics. https:// doi.org/10.1080/00 036846.2019.1644439.

[Ditjenbun] Direktorat Jenderal Perkebunan. 2019. Statistik Perkebunan Indonesia 2018-2020 Kelapa Sawit. Jakarta: Direktorat Jenderal Perkebunan.

Euler M, Hoffman MP, Fathoni Z, Schwarze S. 2016a. Exploring yield gaps in smallholder oil palm production systems in eastern Sumatra, Indonesia. Agricultural Systems 146(2016): 111119. https://doi.org/10.1016/j.agsy.2016.04.007.

Euler M, Schwarze S, Siregar H, Qaim M. 2016b. Oil palm expansion among smallholder farmers in Sumatra, Indonesia. Journal of Agricultural Economics 67(3): 658-676. https://doi. org/10.1111/1477-9552.12163.

[FAO]. Food and Agricultural Organization of the United Nations. 2020. Crop Production Data. Roma. http://www.fao.org/faostat/en/\#data/QC [6 Jan2020].

Gatto, M. Wollni M, Asnawi R, Qaim M. 2017. Oil palm boom, contract farming, and rural economic 
development: Village-level evidence from Indonesia. World Development 95:127-140. https://doi.org/10.1016/j.worlddev.2017.02.013.

Hasnah, Fleming E, Coelli T. 2004. Assessing the performance of a nucleus estate and smallholder scheme for oil palm production in West Sumatra: A stochastic frontier analysis. Agricultural Systems 79(1): 17-30. https://doi.org/10.1016/ S0308-521X(03)00043-X.

Huang CJ, Huang TH, Liu NH. 2014. A new approach to estimating the meta-frontier production function based on a stochastic frontier framework. Journal of Productivity Analysis 42(3): 241-254. https:// doi.org/10.1007/s11123-014-0402-2.

Juyjaeng CO, Suwanmaneepong S, Mankeb P. 2018. Technical efficiency of oil palm production under a large agricultural plot scheme in Thailand. Asian Journal of Scientific Research 11(4): 472479. https://doi.org/10.3923/ajsr.2018.472.479.

Khanal U, Wilson C, Shankar S, Hoang V, Lee B. 2018. Farm performance analysis: Technical efficiencies and technology gaps of Nepalese farmers in different agro-ecological regions. Land Use Policy 76(March): 645-653. https:// doi.org/10.1016/j.landusepol.2018.02.045.

Kittilertpaisan J, Kittilertpaisan K, Khatiwat P. 2016. Technical efficiency of rubber farmers' in Changwat Sakon Nakhon: Stochastic frontier analysis. International Journal of Economics and Financial Issues 6(Special Issue): 138-141.

Koirola KH, Mishra A, Mohanty S. 2016. Impact of land ownership on productivity and efficiency of rice farmers: The case of the Philippines. Land Use Policy 50:371-378. https://doi.org/10.1016/j. landusepol.2015.10.001.

Kramol P, Villano R, Kristiansen P, Fleming E. 2015. Productivity differences between organic and other vegetable farming systems in northern Thailand. Renewable Agriculture and Food Systems 30(2): 154-169. https://doi.org/10.1017/ S1742170513000288.

Melo-Becerra LA, Orozco-Gallo OJ. 2017. Technical efficiency for Colombian small crop and livestock farmers: A stochastic meta-frontier approach for different production systems. Journal of Productivity Analysis 47: 1-16. https://doi. org/10.1007/s11123-016-0487-x .

Ngango J, Kim SG. 2019. Assessment of technical efficiency and its potential determinants among small-scale coffee farmers in Rwanda. Agriculture (Switzerland) 9(7): 1-12. https://doi. org/10.3390/agriculture9070161.

O'Donnell CJ, Rao DSP, Battese GE. 2008. Metafrontier frameworks for the study of firm-level efficiencies and technology ratios. Empirical Economics 34(2): 231-255. https://doi. org/10.1007/s00181-007-0119-4.

Onumah JA, Onumah EE, Al-Hassan RM, Brümmer B. 2013. Meta-frontier analysis of organic and conventional cocoa production in Ghana. Agricultural Economics (Czech Republic) 59(6): 271-280. https://doi.org/10.17221/128/2012AGRICECON.

Rist L, Feintrenie L, Levang P. 2010. The livelihood impacts of oil palm: Smallholders in Indonesia. Biodiversityand Conservation 19(4): 1009-1024. https://doi.org/10.1007/s10531-010-9815-z. 